\title{
PENINGKATAN KEMAMPUAN KOMUNIKASI MAHASISWA PADA MATA KULIAH MANAGEMEN PEMASARAN MENGGUNAKAN METODE KOOPERATIF TIPE JIGSAW
}

\author{
Endah Yuliani ${ }^{1}$, Ratna Nurdiana ${ }^{2}$, Dwi Novaria Misidawati ${ }^{3}$, Siti Aniqoh Shofwani ${ }^{4}$ \\ ${ }^{1,2}$ Unipa Surabaya, ${ }^{3}$ IAIN Pekalongan, ${ }^{4}$ STIE Semarang \\ 4aniqoh2014@gmail.com
}

\begin{abstract}
This research is motivated by the low level of communication in conveying ideas / ideas of students in the learning process in the classroom in the Marketing Management course. The purpose of this study was to improve student communication skills in the Marketing Management course using the Jigsaw cooperative method in class IIA students of the STIE Semarang Management Study Program for the 2019/2020 Academic Year. The subjects of this study were students of class ILA in semester 4 of Management Study Program with 40 students consisting of 32 women and 8 men. This study used the Classroom Action Research (CAR) method referring to the design of the CAR according to Kemmis \& Taggart which consisted of 3 cycles, each of which consisted of planning, implementing, observing, and reflecting. Data collection techniques use observation, tests, documentation, and questionnaires. The results of this study indicate that the jigsaw cooperative method can significantly improve communication skills after three cycles of action. In addition, the jigsaw cooperative method can improve student learning outcomes in Marketing Management courses. Based on the results of the study, it can be concluded that the jigsaw-type cooperative method can improve communication skills to convey ideas and learning outcomes in the Marketing Management course in class ILA students of the STIE Semarang Management Study Program for the 2019/2020 Academic Year.
\end{abstract}

Keywords: Ability, Communication, Marketing Management, Cooperative, Jigsaw

\section{ABSTRAK}

Penelitian ini dilatarbelakangi rendahnya komunikasi menyampaikan gagasan/ide mahasiswa dalam proses pembelajaran di kelas pada mata kuliah Managemen Pemasaran. Tujuan penelitian ini untuk meningkatakan kemampuan komunikasi mahasiswa pada mata kuliah Managemen Pemasaran menggunakan metode Kooperatif tipe Jigsaw pada mahasiswa kelas IIA Prodi Managemen STIE Semarang Tahun Akademik 2019/2020. Subjek penelitian ini mahasiswa kelas IIA semester 4 Prodi Managemen dengan jumlah mahasiswa 40 orang terdiri dari 32 perempuan dan 8 laki-laki. Penelitian ini menggunakan metode Penelitian Tindakan Kelas (PTK) merujuk pada desain pola PTK menurut Kemmis \& Taggart yang terdiri dari 3 siklus, masing-masing siklus terdiri dari perencanaan, pelaksanaan, observasi, dan refleksi. Teknik pengumpulan data menggunaan observasi, tes, dokumentasi, dan angket. Hasil penelitian ini menunjukkan bahwa metode kooperatif tipe jigsaw dapat meningkatkan kemampuan komunikasi yang signifikan setelah dilakukan tindakan sebanyak tiga siklus. Disamping itu, metode kooperatif tipe jigsaw dapat meningkatkan hasil belajar mahasiswa pada mata kuliah Managemen Pemasaran. Berdasarkan hasil penelitian dapat disimpulkan bahwa metode kooperatif tipe jigsaw dapat meningkatkan kemampuan komunikasi menyampaikan gagasan/ide dan hasil belajar mata kuliah Managemen Pemasaran pada mahasiswa kelas IIA Prodi Managemen STIE Semarang Tahun Akademik 2019/2020.

Kata Kunci: Kemampuan, Komunikasi, Managemen Pemasaran, Kooperatif, Jigsaw

Submitted Nov 25, 2020 | Revised Des 13, 2020 | Accepted Des 16, 2020

\section{Pendahuluan}

Kemampuan komunikasi merupakan kemampuan yang penting dalam kegiatan pembelajaran di kelas. Kemampuan ini juga sangat penting dikuasai mahasiswa kaitannya dengan mata kuliah Managemen Pemasaran di Prodi Managemen. Proses pembelajaran akan berjalan dengan baik kalau komunikasi antara dosen dengan mahasiswa, mahasiswa dengan materi, media, dan bahan pembelajaran berjalan tanpa kendala. Penguasaan keterampilan komunikasi akan membantu mahasiswa 
dalam proses pembelajaran mulai dari berpikir, diskusi, presentasi, dan memperoleh pengetahuan/informasi dengan maksimal. Komunikasi dalam kegiatan proses pembelajaran di kelas bisa berbentuk mahasiswa menyampaikan ide/gagasan/pikiran/pendapat dan informasi kepada orang lain untuk tujuan tertentu (Darmuki dkk., 2018: 115). Kegiatan dalam proses pembelajaran membuat kemampuan berkomunikasi menjadi syarat penting karena bisa membantu mahasiswa dan dosen untuk terlibat interaksi multiarah antara dosen dengan mahasiswa, mahasiswa dengan materi, mahasiswa dengan mahasiswa yang lain.

Penguasaan keterampilan komunikasi juga sangat mendukung kegiatan proses pembelajaran lebih aktif dan menyenangkan (Darmuki \& Hariyadi, 2019: 62). Pada konteks pembelajaran, keterampilan dalam berkomunikasi dapat dimaknai sebagai keterampilan yang harus dimiliki dan dikuasai oleh seorang mahasiswa karena keterampilan ini bertujuan untuk menggali pengetahuan sebanyakbanyaknya dan untuk menyampaikan informasi kepada masyarakat baik secara lisan maupun tulisan. Keterampilan berkomunikasi ini menjadi sebuah tantangan tersendiri bagi institusi pendidikan untuk dapat menghasilkan SDM yang peka serta tanggap dengan kondisi yang ada di sekitarnya. Keterampilan komunikasi yang dicerminkan dalam sopan santun mahasiswa dalam bersikap dan bertutur kata agaknya menjadi sebuah pekerjaan rumah bagi pendidik agar pembelajaran yang dilakukan di kelas dapat diterapkan dengan munculnya karakter-karakter mulia seiring dengan melesatnya teknologi dan informasi.

Mata Kuliah Managemen Pemasaran mengajarkan tentang pengembangan konsep-konsep dari manajemen pemasaran yang dikaitkan dengan pengembangan strategi yang digunakan di era globalisasi. Pemahaman mahasiswa terhadap bahasan tersebut akan sangat membantu mahasiswa ketika memasuki dunia kerja khususnya dalam bidang bisnis. Kompetensi ini sangat penting dimiliki oleh mahasiswa Prodi Managemen sebagai bekal pengetahuan dan keterampilan.

Namun kenyataan dalam proses pembelajaran di lapangan menunjukkan pemahaman dan antusias mahasiswa dalam mengikuti mata kuliah ini masih rendah. Dari hasil pengamatan di lapangan, mahasiswa pada saat perkuliahan berlangsung banyak yang kurang memperhatikan penjelasan dari dosen. Diantara mereka banyak yang ngobrol sendiri. Selain itu mereka juga kurang aktif dalam bertanya atau menjawab pertanyaan. Berdasarkan pengamatan di lapangan mahasiswa kurang aktif hal ini disebabkan karena malu, gengsi (takut dianggap tidak pintar), rendahnya kesadaran membaca atau mempersiapkan materi terlebih dahulu, sungkan kepada dosen dan karena metode pembelajarannya kurang sesuai. Akibatnya jika disuruh menjawab pertanyaan secara langsung banyak yang tidak bisa.

Untuk mengatasi masalah tersebut diperlukan penelitian tindakan kelas dengan mengimplementasikan metode pembelajaran kooperatif tipe jigsaw yang harapannya dapat meningkatkan prestasi pembelajaran mata kuliah Managemen Pemasaran pada mahasiswa Manajemen S1 semester IV reguler (Mengduo \& Xiaoling, 2010: 114; Tran, and Lewis, 2012: 10). Model pembelajaran Kooperatif merupakan upaya pembelajaran yang menuntut mahasiswa bekerja dalam kelompok kecil untuk saling membantu mempelajari materi pelajaran (Slavin, 2011). Dalam kelas kooperatif mahasiswa diharapkan untuk saling membantu, berdiskusi, berdebat, saling menilai pengetahuan terbaru dan saling mengisi kelemahan dalam pemahaman masing-masing (Darmuki dan Hidayati, 2019). Dalam penerapan model pembelajaran Kooperatif di mata kuliah managemen pemasaran ini, mahasiswa diminta untuk merancang bangunan sederhana sendiri, dan memecahkan masalah yang ada di dalamnya dalam penggambaran gambar rencana kerja.

Kemampuan komunikasi merupakan kemampuan yang penting dalam kegiatan pembelajaran di kelas (Darmuki dan Hariyadi, 2019: 257). Kemampuan ini juga sangat penting dikuasai mahasiswa kaitannya dengan mata kuliah Managemen Pemasaran di Prodi Managemen. Proses pembelajaran akan berjalan dengan baik kalau komunikasi antara dosen dengan mahasiswa, mahasiswa dengan materi, media, dan bahan pembelajaran berjalan tanpa kendala. Penguasaan keterampilan komunikasi akan membantu mahasiswa dalam proses pembelajaran mulai dari berpikir, diskusi, presentasi, dan 
memperoleh pengetahuan/informasi dengan maksimal. Komunikasi dalam kegiatan proses pembelajaran di kelas bisa berbentuk mahasiswa menyampaikan ide/gagasan/pikiran/pendapat dan informasi kepada orang lain untuk tujuan tertentu (Darmuki dkk., 2018: 115). Kegiatan dalam proses pembelajaran membuat kemampuan berkomunikasi menjadi syarat penting karena bisa membantu mahasiswa dan dosen untuk terlibat interaksi multiarah antara dosen dengan mahasiswa, mahasiswa dengan materi, mahasiswa dengan mahasiswa yang lain.

Penguasaan keterampilan komunikasi juga sangat mendukung kegiatan proses pembelajaran lebih aktif dan menyenangkan (Darmuki \& Hariyadi, 2019: 62). Pada konteks pembelajaran, keterampilan berkomunikasi dapat dimaknai sebagai keterampilan yang harus dimiliki dan dikuasai oleh seorang mahasiswa karena keterampilan ini bertujuan untuk menggali pengetahuan sebanyak-banyaknya dan untuk menyampaikan informasi kepada masyarakat baik secara lisan maupun tulisan (Darmuki dan Hidayati, 2019: 10). Keterampilan berkomunikasi ini menjadi sebuah tantangan tersendiri bagi institusi pendidikan untuk dapat menghasilkan SDM yang peka serta tanggap dengan kondisi yang ada di sekitarnya. Keterampilan komunikasi yang dicerminkan dalam sopan santun mahasiswa dalam bersikap dan bertutur kata agaknya menjadi sebuah pekerjaan rumah bagi pendidik agar pembelajaran yang dilakukan di kelas dapat diterapkan dengan munculnya karakter-karakter mulia seiring dengan melesatnya teknologi dan informasi.

Mata Kuliah Managemen Pemasaran mengajarkan tentang pengembangan konsep-konsep dari manajemen pemasaran yang dikaitkan dengan pengembangan strategi yang digunakan di era globalisasi. Pemahaman mahasiswa terhadap bahasan tersebut akan sangat membantu mahasiswa ketika memasuki dunia kerja khususnya dalam bidang bisnis. Kompetensi ini sangat penting dimiliki oleh mahasiswa Prodi Managemen sebagai bekal pengetahuan dan keterampilan.

Namun kenyataan dalam proses pembelajaran di lapangan menunjukkan pemahaman dan antusias mahasiswa dalam mengikuti mata kuliah ini masih rendah. Dari hasil pengamatan di lapangan, mahasiswa pada saat perkuliahan berlangsung banyak yang kurang memperhatikan penjelasan dari dosen. Diantara mereka banyak yang ngobrol sendiri. Selain itu mereka juga kurang aktif dalam bertanya atau menjawab pertanyaan. Berdasarkan pengamatan di lapangan mahasiswa kurang aktif hal ini disebabkan karena malu, gengsi (takut dianggap tidak pintar), rendahnya kesadaran membaca atau mempersiapkan materi terlebih dahulu, sungkan kepada dosen dan karena metode pembelajarannya kurang sesuai. Akibatnya jika disuruh menjawab pertanyaan secara langsung banyak yang tidak bisa.

Untuk mengatasi masalah tersebut diperlukan penelitian tindakan kelas dengan mengimplementasikan metode pembelajaran kooperatif tipe jigsaw yang harapannya dapat meningkatkan prestasi pembelajaran mata kuliah Managemen Pemasaran pada mahasiswa Manajemen S1 semester IV reguler.

\section{Metode Penelitian}

Metode yang digunakan dalam penelitian ini adalah metode Penelitian Tindakan Kelas (classroom action research). Penelitian Tindakan Kelas, menurut Kemmis dan Mc Taggart, dapat dipandang sebagai suatu siklus spiral dari penyusunan perencanaan, pelaksanaan tindakan, pengamatan (observasi), dan refleksi yang selanjutnya mungkin diikuti dengan siklus spiral berikutnya. Penelitian tindakan kelas ini dilaksanakan pada mahasiswa kelas IIA semester 4 Prodi Managemen dengan jumlah mahasiswa 40 orang terdiri dari 32 perempuan dan 8 laki-laki. Penelitian ini dilaksanakan selama 8 kali pertemuan dan pelaksanaanya disesuaikan dengan jadwal kegiatan pembelajaran di kelas.

Teknik pengumpulan data dilakukan melalui observasi, wawancara dan dokumentasi. Observasi dilakukan terhadap subjek penelitian yaitu aktivitas dosen mitra dan mahasiswa kelas IIA semester 4 selama masa tindakan yang dilaksanakan berdasarkan siklus pembelajaran yang sudah direncanakan. Kegiatan observasi terhadap mahasiswa dilakukan dengan menganalisis dan mencatat secara sistematis mengenai keterampilan komunikasi mahasiswa dengan melihat dan mengamati mereka dalam 
kelompok secara langsung saat proses pembelajaran mata kuliah managemen pemasaran yang menggunakan model pembelajaran kooperatif tipe jigsaw dengan menggunakan instrument observasi yang memuat indikator-indikator keterampilan komunikasi mahasiswa. Sedangkan observasi terhadap dosen mitra dilakukan dengan mengamati proses pembelajaran dengan menggunakan pedoman berupa instrument supervisi dosen berdasarkan kurikulum KKNI yang diterapkan di lokasi penelitian.

Selain observasi, teknik pengumpulan data juga dilakukan melalui wawancara bebas kepada dosen mitra maupun mahasiswa dengan mengajukan pertanyaan-pertanyaan spontan kepada mahasiswa berkaitan mengenai respon mereka terhadap teknik pembelajaran yang digunakan. Begitupun dengan wawancara yang dilakukan terhadap dosen mitra, dilakukan dalam suasana nonformal untuk mendapatkan gambaran tentang proses pembelajaran sebelum dilakukan penelitian, dan juga saat melakukan refleksi usai melakukan tindakan dalam setiap siklusnya. Adapun dokumen yang digunakan oleh peneliti diantaranya adalah silabus pembelajaran, rencana pelaksanaan pembelajaran, daftar nilai post-test, serta gambar atau foto mahasiswa saat proses pembelajaran managemen pemasaran di kelas dengan menggunakan teknik jigsaw.

Selama observasi berlangsung, semua aktivitas dosen mitra dan mahasiswa dituangkan ke dalam sebuah catatan lapangan (field notes). Indikator- indikator keberhasilan pembelajaran dosen dibuat dalam kategori pada aspek yang diamati yaitu apabila dosen sudah menunjukkan lebih dari $80 \%(>80 \%)$ dengan kategori baik dalam pembelajarannya. Sementara indikator- indikator keberhasilan pembelajaran mahasiswa dibuat dalam kategori pada aspek yang diamati yaitu apabila mahasiswa sudah menunjukkan peningkatan keterampilan social dengan kategori baik (B) dalam setiap pembelajarannya. Adapun kategori-kategori dimaksud adalah sebagai berikut: a) Apabila kurang dari $60 \%(<60 \%)=$ Kurang (K); b) Apabila 60\% - 70\% = Cukup (C); dan c) Apabila lebih dari 70\% (>70\%)= Baik (B).

\section{Hasil dan Pembahasan}

Tindakan dalam penelitian ini dilaksanakan dalam tiga siklus yang terdiri atas dua tindakan dalam siklus pertama (20 dan 22 Januari 2020), dua tindakan dalam siklus ke-dua (12 dan 17 Februari 2020) serta satu tindakan dalam siklus ke- tiga (19 Februari 2020). Sebelum melaksanakan tindakan, peneliti dan dosen mitra melakukan diskusi dan membuat kesepakatan mengenai hal-hal yang akan dilakukan dalam setiap tindakan.

Dalam penelitian ini, tidak ada perlakuan khusus selain pembelajaran kooperatif dengan langkahlangkah teknik jigsaw yang sebelumnya sudah dikomunkasikan bersama sesuai dengan langkah-langkah pembelajaran yang telah dijelaskan dalam teori. Begitu pula dengan mahasiswa, tidak ada perlakuan khusus yang dilakukan kepada mahasiswa berkenaan dengan proses pembelajaran. Pembelajaran mengalir sebagaimana biasanya.

Dokumen pelaksanaan pembelajaran (RPP) dibuat bersama-sama dengan merujuk kepada Kompetensi Inti, Kompetensi Dasar, indikator pencapaian kompetensi, sumber dan media yang digunakan serta materi yang disampaikan merujuk kepada silabus sesuai dengan amanat kurikulum KKNI. Dalam pelaksanaan pembelajaran, sumber dan media pembelajaran diserahkan kepada dosen mitra. Dengan kurikulum KKNI yang diterapkan di lokasi penelitian yang didukung oleh sarana pembelajaran yang memadai di setiap kelas, membuat dosen tidak mengalami kesulitan dalam membuat dan menampilkan media pembelajaran untuk mengoptimalkan kegiatan pembelajaran yang dijiwai oleh pendekatan scientific yaitu mengamati, menanya menalar, menggali informasi dan mengkomunikasikan.

Pada siklus I, tindakan difokuskan untuk mengamati indikator menggali informasi dalam kelompok ahli dan menyampaikan materi saat mahasiswa berperan sebagai narasumber. Mahasiswa melaksanakan tindakan pembelajaran dengan kooperatif namun keterampilan berkomunikasi belum 
dikuasai secara merata oleh seluruh anggota dalam kelompok. Masih ada mahasiswa yang mendominasi kelompok sementara mahasiswa lainnya belum menunjukkan kepercayaan diri yang cukup baik.

Pada siklus II, mahasiswa mulai terbiasa dengan model pembelajaran kooperatif tipe jigsaw yang ditunjukkan dengan tumbuhnya inisiatif, kekompakan serta kerjasama yang cukup baik dalam kelompok. Diskusi dalam kelompok, baik dalam kelompok asal maupun kelompok ahli tampak lebih hidup dan kepercayaan diri mahasiswa dalam mengemukakan gagasan serta mengajukan pertanyaan mengalami peningkatan. Dominasi mahasiswa tertentu dalam kelompok mulai berkurang. Hal ini diperkuat dalam siklus III dimana setiap tim ahli tampil ke depan kelas untuk mempresentasikan materi pembahasannya dalam bentuk power point.

Setiap kelompok ahli mengatur pergiliran presentasi anggotanya sedemikian rupa sehingga semua anggota kelompok ahli tersebut memiliki kesempatan yang sama dalam mengemukakan gagasan, menyanggah, atau menjawab pertanyaan. Mahasiswa dalam kelompok lainnya juga tidak sungkan memberi pertanyaan untuk hal- hal yang belum dipahami dan untuk mengkonfirmasi pemahaman yang dimilikinya. Distribusi materi berbentuk pertanyaan yang sifatnya menalar dan kegiatan presentasi kelompok ahli dalam bentuk power point cukup efektif dalam upaya mengoptimalkan keterampilan komunikasi mahasiswa dalam pembelajaran di kelas.

Berdasarkan observasi yang dilakukan juga dapat diketahui bahwa ternyata model pembelajaran kooperatif tipe jigsaw selain dapat meningkatkan aktivitas mahasiswa dalam mengasah keterampilan komunikasinya, juga ternyata menumbuhkan kemandirian mahasiswa dalam menemukan konsep belajarnya melalui aktivitas menggali informasi tentang materi, meningkatkan kerjasama serta kekompakan dalam kelompok, serta dapat menumbuhkan rasa tanggung jawab. Hal ini disebabkan karena setiap mahasiswa akan menentukan keberhasilan kelompoknya dalam memahami setiap materi yang berimbas kepada pencapaian hasil yang diperoleh dalam post-test.

Selain keterampilan komunikasi peserta didik, kompetensi pembelajaran dosen mitra pun mengalami peningkatan yang signifikan. Pada siklus pertama, dosen mitra terlihat belum menguasai model pembelajaran kooperatif tipe jigsaw karena masih tampak mendominasi kelas, namun pada siklus berikutnya dosen mitra cukup berhasil memotivasi mahasiswa untuk mengemukakan gagasan dan mengajukan pertanyaan atas inisiatif sendiri. Selain itu, aspek pengetahuan (ranah kognitif) mahasiswa juga mengalami peningkatan. Hal ini dilihat dari hasil evaluasi (post-test) yang dilakukan sebanyak dua kali dimana mahasiswa dan kelompok yang memiliki nilai di atas KKM mengalami peningkatan.

Berdasarkan tiga siklus yang dilakukan, menunjukkan peningkatan dalam kompetensi pembelajaran yang dilakukan oleh dosen mitra. Berdasarkan observasi yang dilakukan pada siklus I, penguasaan kompetensi pembelajaran dosen yang sudah muncul dan dikuasai dengan baik adalah sebesar 59\% (kategori K). Aspek yang perlu ditingkatkan adalah dalam hal penguasaan kelas, memberikan iklim yang mendukung dalam pembelajaran aktif, kontekstualitas materi serta kemampuan membuka dan menutup pembelajaran. Pada siklus II, penguasaan kompetensi pembelajaran dosen meningkat menjadi 79\% (kategori C) dimana dosen sudah mulai menegaskan aturan main dan memotivasi mahasiswa untuk aktif melakukan komunikasi dalam kelas.

Dominasi dosen mulai dapat dikurangi. Pada siklus III, peningkatan kompetensi pembelajaran dosen meningkat signifikan menjadi $92 \%$ (kategori $A B$ ), dimana suasana pembelajaran semakin stabil dan dosen mitra berhasil menguasai kelas dengan baik serta menciptakan iklim yang membuat mahasiswa merasa nyaman dan percaya diri dalam mengasah keterampilan komunikasinya. Sebagaimana kompetensi pembelajaran dosen, berdasarkan lima kali tindakan yang terangkum dalam III siklus penelitian menunjukkan bahwa keterampilan komunikasi mahasiswa juga mengalami peningkatan yang signifikan. Hal ini ditunjukkan dengan meningkatnya jumlah mahasiswa yang berpartisipasi aktif dalam menampilkan aspek-aspek yang relevan dengan indikator keterampilan komunikasi. Deskrmanagemen pemasaran inya adalah sebagai berikut: 
1) Pada indikator menggali informasi dan data mengalami peningkatan $27 \%$, dimana dalam siklus I hanya 20 orang, menjadi 23 orang dalam siklus II, dan 28 orang mahasiswa dalam siklus III.

2) Pada indikator menyampaikan materi dengan jelas, terdapat peningkatan $27 \%$ dimana dalam siklus I hanya 22 orang peserta didik, meningkat menjadi 25 orang dalam siklus II, dan 30 orang dalam siklus III.

3) Pada indikator mengemukakan pendapat terdapat peningkatan sebesar $40 \%$. Dalam siklus I hanya 13 orang mahasiswa, meningkat menjadi 20 orang dalam siklus II, dan 25 orang dalam siklus III.

4) Indikator dalam aspek kemampuan merespon informasi terbagi atas indikator mendengarkan pendapat dan indikator mengajukan pertanyaan. Indikator mendengarkan pendapat mengalami peningkatan sebesar 33\%. Dalam siklus I hanya terdapat 20 orang mahasiswa yang menunjukkan sikap fokus dalam mendengarkan penjelasan teman-temannya, meningkat menjadi 26 orang dalam siklus II, dan 30 orang dalam siklus III. Adanya tantangan untuk post-test dan presentasi kelompok ahli membuat diskusi berjalan dengan lebih maksimal dengan respon positif yang ditunjukkan oleh mahasiswa.

5) Pada indikator mengajukan pertanyaan, terdapat peningkatan sebesar $47 \%$ dimana dalam siklus I hanya terdapat 10 orang mahasiswa, meningkat menjadi 16 orang dalam siklus II, dan 24 orang dalam siklus III.

Meskipun hasil belajar ini bukan merupakan aspek yang menjadi objek penelitian, namun proses evaluasi belajar tetap dilakukan oleh peneliti untuk mengukur keberhasilan teknik jigsaw yang ditinjau dari aspek kognitif. Pertanyaan yang diberikan pun berbeda dari dua kali post-test yang dilakukan. Dalam post-test pertama, evaluasi dibuat oleh dosen mitra dengan menggunakan pertanyaan yang bersifat mengingat konsep (re-call). Sedangkan dalam post- test II, evaluasi dibuat oleh peneliti (dengan tetap berkoordinasi kepada dosen mitra) dan pertanyaan yang dibuat dikombinasikan antara pertanyaan yang mengingat konsep (C1) dan mengukur pemahaman mahasiswa (C2).

Berdasarkan data hasil evaluasi, dapat diketahui bahwa jumlah mahasiswa yang memiliki nilai di atas KKM (76) dalam post-test I adalah 20 orang (67\%). Jika dihitung nilai rata-rata kelompok asal, dari 5 kelompok yang dibentuk hanya 2 kelompok saja (40\%) yang nilai rata-rata kelompoknya di atas KKM. Sedangkan dalam post-test II, jumlah mahasiswa yang memiliki nilai di atas KKM sebanyak 25 orang yaitu $83 \%$ dari total 30 orang mahasiswa, dan seluruh nilai rata-rata kelompok berada di atas KKM.

Beberapa penelitian yang dilakukan sebelumnya juga menunjukkan adanya peningkatan hasil belajar dari aspek kognitif melalui penerapan model pembelajaran kooperatif tipe jigsaw ini, diantaranya penelitian yang dilakukan oleh Darmuki dkk. (2019) bahwa model pembelajaran kooperatif teknik jigsaw dapat meningkakan hasil belajar mahasiswa Prodi PBSI Darmuki dkk. (2019) bahwa model pembelajaran kooperatif teknik jigsaw dapat meningkatkan hasil belajar mahasiswa.

\section{Kesimpulan}

Berdasarkan hasil analisis yang dilakukan selama pelaksanaan tindakan, baik pada siklus I, II maupun siklus III, maka beberapa poin yang menjadi kesimpulan pada penelitian ini yaitu Pertama, desain perencanaan pembelajaran model pembelajaran kooperatif tipe jigsaw terealisasi dalam lima tindakan yang terangkum dalam tiga siklus yang pelaksanaannya tidak ada perlakuan khusus terhadap kondisi kelas dan peserta didik. Pembelajaran berlangsung sebagaimana biasanya.

Kedua, yaitu tahapan-tahapan pelaksanaan pembelajaran dengan model pembelajaran kooperatif tipe jigsaw yaitu pembelajaran diawali dengan kegiatan pengamatan yang akan memancing rasa ingin tahu mahasiswa terhadap konsep atau materi yang akan menjadi bahan pembahasannya. Selanjutnya dibentuk kelompok-kelompok kecil sebanyak enam kelompok dimana masing-masing kelompok terdiri atas lima orang anggota yang masing-masing akan mendapatkan materi yang berbeda-beda untuk 
dibahas. Kemudian, mahasiswa yang mendapatkan tema yang sama berkumpul dalam satu kelompok untuk membentuk kelompok ahli.

Ketiga, hasil-hasil yang dicapai dalam pembelajaran yang menggunakan model pembelajaran kooperatif tipe jigsaw yaitu penguasaan kompetensi pembelajaran dengan kategori baik mengalami peningkatan signifikan, kategori cukup (C) dalam siklus sebelumnya meningkat menjadi kategori Amat Baik (AB) pada siklus III. Begitupun dengan penguasaan keterampilan komunikasi peserta didik, pada siklus I berada dalam kategori kurang (K), meningkat menjadi kategori Baik (B) dalam siklus II, dan meningkat persentasinya secara signifikan dalam siklus III yaitu sebesar $91.2 \%$. Sementara itu, berdasarkan hasil evaluasi yang dilakukan diperoleh informasi bahwa ada peningkatan hasil belajar peserta didik. Pada post-test I, jumlah mahasiswa yang mencapai KKM adalah sebanyak 20 orang, sedangkan dalam post-test II jumlah peserta didik yang nilainya mencapai KKM meningkat menjadi 25 orang. Hal ini berarti penguasaan ranah kognitif peserta didik mengalami peningkatan sebesar $16 \%$.

Keempat, dalam penerapan model pembelajaran kooperatif teknik jigsaw, terdapat beberapa kendala yang dialami, diantaranya adalah: (1) Penerapan teknik jigsaw dalam pembelajaran memerlukan waktu yang relatif lama. Proses diskusi dan penggalian materi yang melibatkan peran aktif seluruh mahasiswa memerlukan waktu beberapa kali pertemuan sehingga waktu yang dibutuhkan dalam menuntaskan sebuah materi menjadi lebih panjang.

Berdasarkan penjelasan tersebut, maka diperlukan suatu perencanaan yang matang yang dituangkan dalam rencana pelaksanaan pembelajaran sehingga durasi pembelajaran dapat dimanfaatkan secara optimal sekaligus mengasah keterampilan peserta didik; (2) Tidak semua materi managemen pemasaran relevan diterapkan dengan teknik jigsaw, oleh karena itu diperlukan keterampilan dosen dalam pemilahan materi. Materi yang disajikan harus dipilah-pilah untuk dikaji oleh lima sampai enam orang dalam satu kelompok.

Materi-materi tersebut jika diuraikan oleh masing-masing orang akan membentuk konsep-konsep yang berintegrasi atau memiliki hubungan; (3) Model pembelajaran kooperatif tipe jigsaw ini dapat menjadi salah satu alternatif teknik yang pembelajaran yang digunakan dalam meningkatkan keterampilan komunikasi peserta didik. Namun, tetap diperlukan keterampilan dosen dalam mengasah keterampilan bertanya yang dapat memancing minat peserta didik untuk mengungkapkan argumentasinya; (4) Dalam model pembelajaran teknik jigsaw, pembelajaran didominasi dengan diskusi antar kelompok sehingga terkadang suasana kelas menjadi sedikit gaduh. Oleh karena itu, dosen perlu lebih optimal dalam menegaskan aturan main sehingga setiap mahasiswa dapat fokus dengan kegiatan diskusinya; (5) Peserta didik yang memiliki karakter pendiam agak sulit untuk ditumbuhkan inisiatifnya dalam melakukan komunikasi di kelas. Oleh sebab itu, dalam siklus II, peneliti dan dosen mitra sepakat mengadakan presentasi kelompok ahli untuk lebih memastikan bahwa setiap mahasiswa mendapat kesempatan yang seluas- luasnya dalam mengemukakan argumentasinya. Termasuk untuk memancing mahasiswa yang karakternya pendiam tersebut.

\section{Daftar Pustaka}

Darmuki, A. \& Ahmad Hariyadi. (2019). Eksperimentasi Model Pembelajaran Jucama Ditinjau Dari Gaya Belajar Terhadap Prestasi Belajar Mahasiswa Mata Kuliah Berbicara Di Prodi PBSI IKIP PGRI Bojonegoro. Kredo. 3(1), 62-72.

Darmuki, A. \& Hidayati N.A. (2019). An Investigation of The Cooperative Learning Using Audio Visual Media in Speaking Skill Subject. ICSTI. 121-126.

Darmuki, A. \& Hidayati, N.A. (2019). Peningkatan Kemampuan Berbicara Menggunakan Metode Kooperatif Tipe NHT pada Mahasiswa Tingkat I-A Prodi PBSI IKIP PGRI Bojonegoro Tahun Akademik 2018/2019. Jurnal Pendidikan Edutama. Vol. 6(2), hlm 9-18. 
Darmuki, A., Ahmad Hariyadi. (2019). Peningkatan Keterampilan Berbicara Menggunakan Metode Kooperatif Tipe Jigsaw pada Mahasiswa PBSI Tingkat IB IKIP PGRI Bojonegoro Tahun Akademik 2018/2019. Kredo. 2(2), 256-267.

Darmuki, A., Andayani, Joko Nurkamto, Kundharu Saddhono. (2017). Cooperative, Synectics, and CTL Learning Models Toward Speaking Ability Viewd from Students Motivation. Proceeding International Conference on Intellectuals'Global Responsibility (ASSEHR). Vol. 125, 75-79.

Darmuki, A., Andayani, Joko Nurkamto, Kundharu Saddhono. (2017). Evaluating InformationProcessing-Based Learning Cooperative Model on Speaking Skill Course. Journal of Language Teaching and Reasearch. 8(1) pp. 44-51.

Darmuki, A., Andayani, Joko Nurkamto, Kundharu Saddhono. (2018). The Development and Evaluation of Speaking Learning Model by Cooperative Approach. International Journal of Instruction. 11(2), 115-128.

Darmuki, A., Ahmad Hariyadi, Nur Alfin Hidayati. (2019). Developing Beach Ball Group Investigations Cooperative. International Conferences Seword Fresh, 1-7.

Mengduo, Q., \& Xiaoling, J. (2010). Jigsaw Strategy as a Cooperative Learning Technique: Focusing on the Language Learners. Chinese Journal of Applied Linguistics, 33(4), 113-125.

Slavin, R.E. (2011). Cooperative learning teori, riset dan praktik. Bandung: Nusa Media.

Tran, V.D. and R. Lewis. (2012). The effects of Jigsaw learning on students' attitudes in a Vietnamese higher education classroom. International Journal of Higher Education, vol. 1, pp. 9-20. 